\title{
PROFIL PENDERITA LUKA BAKAR AKIBAT LISTRIK \\ DI BLU RSU PROF. DR. R. D. KANDOU MANADO PERIODE AGUSTUS 2009 - AGUSTUS 2012
}

\author{
${ }^{1}$ Shinta D. Siahaan \\ ${ }^{2}$ Alwin Monoarfa \\ ${ }^{3}$ Mendy Hatibie \\ ${ }^{1}$ Kandidat Fakultas Kedokteran Unsrat \\ ${ }^{2}$ Bagian Ilmu Bedah Fakultas Kedokteran Universitas Sam Ratulangi \\ Email: shinta_siahaan91@yahoo.com
}

\begin{abstract}
Background: Electrical burns are caused by direct contact electric with the body, and often wound more serious than what is visible on the surface. Electric current can cause injury in three ways: Cardiac arrest (cardiac arrest) due to electrical effects on the heart; damage to muscles, nerves, and tissues by electric current through the body; thermal burns due to contact with the power source. The purpose of this study was to determine the profile of patients with electrical burns on BLU RSU Prof. Dr. R. D. Manado Kandou for period August 2009-August 2012.

Methods: This study used a retrospective descriptive study method by the medical record data on BLU RSU Prof. Dr. R. D. Kandou Manado August 2009-August 2012.

Results: The total cases of electrical burns are 40 cases, with 15 cases on period of August 2009 to August 2010, 9 cases on period of August 2010 to August 2011, and on period August 2011 to August 2012 found are 16 cases. Most incidents occurred in the age of 25-44 years with more incident occurred to men. Seen from the work, most incidence is occupied by the employees construction workers. Based on the strength of electric current, the highest incidence in medium voltage (domestic installations), which indicates that the housekeeping installation is not good, using of low quality cable, no electrical installation checks on a regular basis, using of cable rollers with excessive load, and using incorrect electrical tools. All of those items increasing the incidence rate.

Conclusion: The accident caused electricity easily happen to anyone. Most of those who work in place are susceptible to electrical currents. On illegal electricity usage may also increase the risk of electricity. In children which less supervision from their parents can also occur. These facts required tights attention from all parties to realize unsafe power consumption and attention to safety themselves.
\end{abstract}

Keywords: Profiles, electrical burns, handling

\begin{abstract}
Abstrak
Latar belakang: Luka bakar listrik disebabkan oleh kontak langsung aliran listrik dengan badan, dan sering lukanya lebih serius dari apa yang terlihat di permukaan. Arus listrik dapat menyebabkan cedera dalam tiga cara: Henti jantung (cardiac arrest) akibat efek listrik pada jantung; kerusakan otot, saraf, dan jaringan oleh arus listrik yang melewati tubuh; luka bakar thermal akibat kontak dengan sumber listrik. Tujuan penelitian ini adalah untuk mengetahui profil penderita luka bakar akibat listrik di BLU RSU Prof. Dr. R. D. Kandou Manado periode Agustus 2009-Agustus 2012.

Metode: Penelitian ini menggunakan metode retrospektif deskriptif melalui penelitian data rekam medik di BLU RSU Prof. Dr. R. D. Kandou Manado Agustus 2009-Agustus 2012.

Hasil: Keseluruhan luka bakar listrik sebanyak 40 kasus, yaitu 15 kasus pada periode Agustus 2009 - Agustus 2010, 9 kasus pada periode Agustus 2010 - Agustus 2011, dan pada periode Agustus 2011 - Agustus 2012 didapatkan sebanyak 16 kasus. Insiden terbanyak terjadi pada umur 25-44 tahun dengan insiden terjadi lebih banyak pada pria. Dilihat dari pekerjaan terbanyak, insiden terbanyak
\end{abstract}


ditempati oleh para pekerja buruh bangunan. Berdasarkan kuat arus listrik, insiden terbanyak adalah voltase menengah (instalasi rumah tangga), yang menunjukkan bahwa instalasi rumah tangga yang tidak baik, penggunaan kabel kualitas rendah, tidak adanya pengecekan instalasi listrik secara teratur, penggunaan kabel rol dengan beban berlebihan, serta penggunaan alat-alat listrik yang tidak benar, menyebabkan insiden meningkat.

Kesimpulan: Kecelakaan akibat listrik mudah terjadi pada siapa saja. Kebanyakan bagi mereka yang bekerja ditempat yang rentan dengan arus listrik. Kemudian pada pemakaian listrik illegal juga dapat meningkatkan resiko terjadinya listrik.Pada anak-anak yang kurang pengawasan dari orang tuanya pun dapat terjadi. Meningkatnya angka kejadian ini mendapat perhatian dari berbagai pihak untuk menyadari pemakaian listrik yang tidak aman dan memperhatikan keselamatan diri sendiri.

Kata kunci: Profil, luka bakar listrik, penanganan.

Kejadian syok listrik merupakan kejadian yang timbul secara kebetulan. Tidak mengherankan dengan meluasnya pemakaian listrik di rumah tangga dan industri kerja, syok listrik akan meningkat. ${ }^{1}$ Dengan adanya listrik masuk desa, tentunya meningkatkan pula kemungkinan akan trauma listrik, lebih-lebih masyarakat belum banyak mengenal usaha pengamanannya. ${ }^{2}$

Luka bakar listrik disebabkan oleh kontak langsung aliran listrik dengan badan, dan sering lukanya lebih serius dari apa yang terlihat di permukaan. Tubuh manusia dapat bertindak sebagai penghantar energi listrik dan mengakibatkan kerusakan jaringan akibat panas yang ditimbulkannya. ${ }^{3}$ Antara 3\% dan 5\% dari rawat inap unit luka bakar berhubungan dengan luka bakar listrik. ${ }^{4}$

Luka bakar akibat listrik tegangan tinggi dihadapkan pada mortalitas yang tinggi. ${ }^{5}$ Lewatnya tenaga listrik bervoltase tinggi melalui jaringan menyebabkan perubahannya menjadi tenaga panas. Ia menimbulkan luka bakar yang tidak hanya mengenai kulit dan jaringan subkutis, tetapi juga semua jaringan pada jalur arus listrik tersebut. ${ }^{6}$ Sedangkan luka bakar akibat listrik tegangan rendah diikuti oleh kerusakan jaringan dengan progresivitas yang berjalan lambat, namun memiliki morbiditas dan mortalitas tinggi. Kerusakan jaringan tubuh dibedakan dalam dua golongan. Pertama, disebabkan oleh arus listrik melalui jaringan tubuh (electrical shock) dan jenis kedua, disebabkan oleh arc (percikan, letupan, ledakan, electrical flash) energi listrik. ${ }^{5,7}$

Setiap luka bakar akibat sengatan listrik harus diperiksa dokter. Luka bakar akibat listrik mungkin kelihatannya ringan, namun kerusakannya bisa sampai jauh ke dalam jaringan bawah kulit. ${ }^{8}$ Arus listrik dapat menyebabkan cedera dalam tiga cara: Henti jantung (cardiac arrest) akibat efek listrik pada jantung; kerusakan otot, saraf, dan jaringan oleh arus listrik yang melewati tubuh; luka bakar thermal akibat kontak dengan sumber listrik. ${ }^{2,9}$ Kadangkadang sentakan akibat sengatan listrik bisa mengakibatkan orang yang bersangkutan terlempar atau jatuh, sehingga menimbulkan patah tulang atau cedera lainnya. ${ }^{8}$

Bahaya syok listrik sangat besar; tubuh penderita akan mengalami vebtricular vibrillation, kemudian diikuti dengan kematian. ${ }^{1,10}$ Kehadiran luka bakar yang parah (umumnya dalam tegangan tinggi cedera listrik), nekrosis miokard, tingkat cedera sistem saraf pusat, dan kegagalan sistem organ multiple sekunder menentukan morbiditas berikutnya dan prognosis jangka panjang. ${ }^{10}$

\section{METODE PENELITIAN}

Penelitian ini bersifat deskriptif retrospektif melalui penelitian data rekam medik di BLU RS Prof. Dr. R. D. Kandou Manado periode Agustus 2009-Agustus 2012. Subjek penelitian merupakan seluruh penderita luka bakar akibat listrik di Rekam Medik BLU RS Prof. Dr. R. D. Kandou Manado periode Agustus 2009-Agustus 2012. Variabel penelitian terdiri atas umur, jenis kelamin, pekerjaaan, besarnya kuat arus listrik, keadaan awal pasien, dan keadaan akhir pasien. 


\section{HASIL PENELITIAN}

\section{A. Frekuensi Luka Bakar Listrik}

Berdasarkan hasil pencatatan dari Rekam Medik BLU RSU Prof. Dr. R. D. Kandou Manado bahwa dalam periode Agustus 2009 - Agustus 2012 ada 40 kasus. Tiap periode tersebut memiliki jumlah kasus yang berbeda-beda. Pada periode Agustus 2009 - Juli 2010 terdapat sebanyak 15 kasus, periode Agustus 2010 - Juli 2011 sebanyak 9 kasus, dan periode Agustus 2011 - Agustus 2012 sebanyak 16 kasus.

\section{A.1. Profil Luka Bakar Listrik}

\section{A.1.1. Distribusi menurut umur}

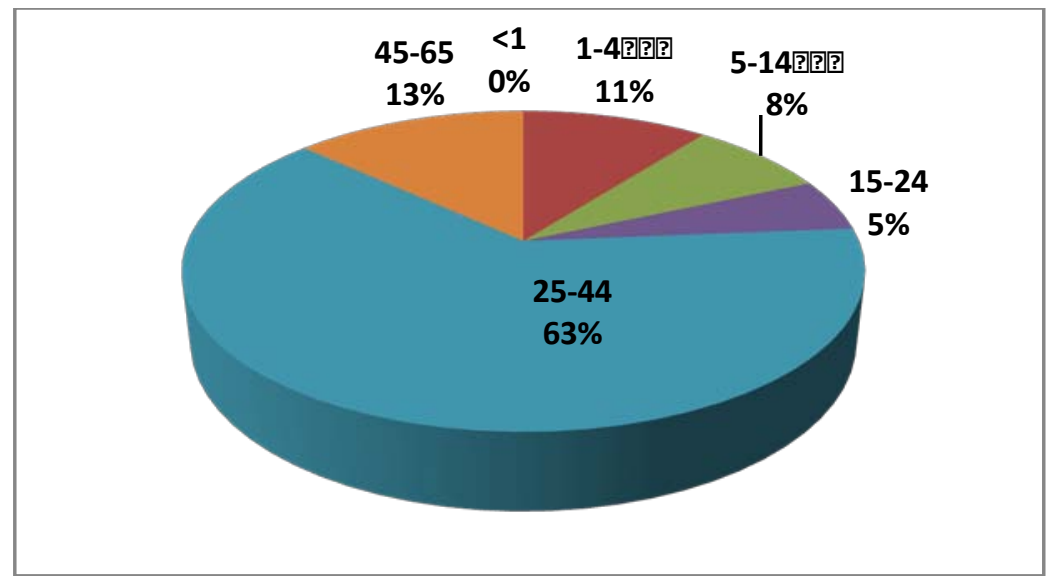

Gambar 1. Distribusi penderita luka bakar listrik berdasarkan umur

Dari 40 kasus luka bakar listrik yang dirawat di Instalasi Rawat Inap Bedah (Irina A) RSU Prof. Dr. R. D. Kandou Manado periode Agustus 2009 - Agustus 2012, tabel I menunjukkan bahwa insiden terbanyak terjadi pada rentang umur 25-44 tahun sebanyak 24 kasus (60\%), diikuti oleh rentang umur 45-65 tahun sebanyak 5 kasus (12,5\%), diikuti oleh rentang umur 1-4 tahun sebanyak 4 kasus (10\%), diikuti oleh rentang umur 5-14 tahun sebanyak 3 kasus (7,5\%), kemudian diikuti oleh 2 jenis rentang umur yang memiliki jumlah kasus yang sama yaitu rentang umur 15-24 tahun sebnyak 2 kasus (5\%) dan rentang umur $>65$ tahun sebanyak 2 kasus (5\%).

\section{A.1.2. Distribusi menurut jenis kelamin}

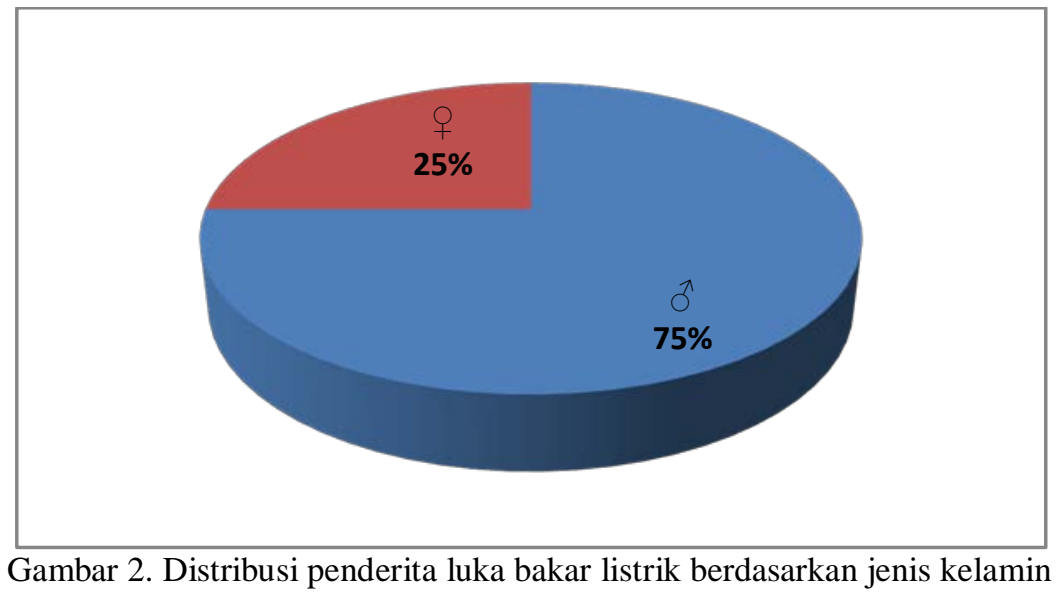


Dari 40 kasus luka bakar listrik yang dirawat di Instalasi Rawat Inap Bedah (Irina A) RSU Prof. Dr. R. D. Kandou Manado periode Agustus 2009 - Agustus 2012, berdasarkan jenis kelamin, tabel II menunjukkan bahwa insiden tertinggi terjadi pada pria dengan jumlah kasus sebanyak 30 kasus (75\%), sedangkan sebanyak 10 kasus (25\%) terjadi pada wanita.

\section{A.1.3. Distribusi menurut pekerjaan}

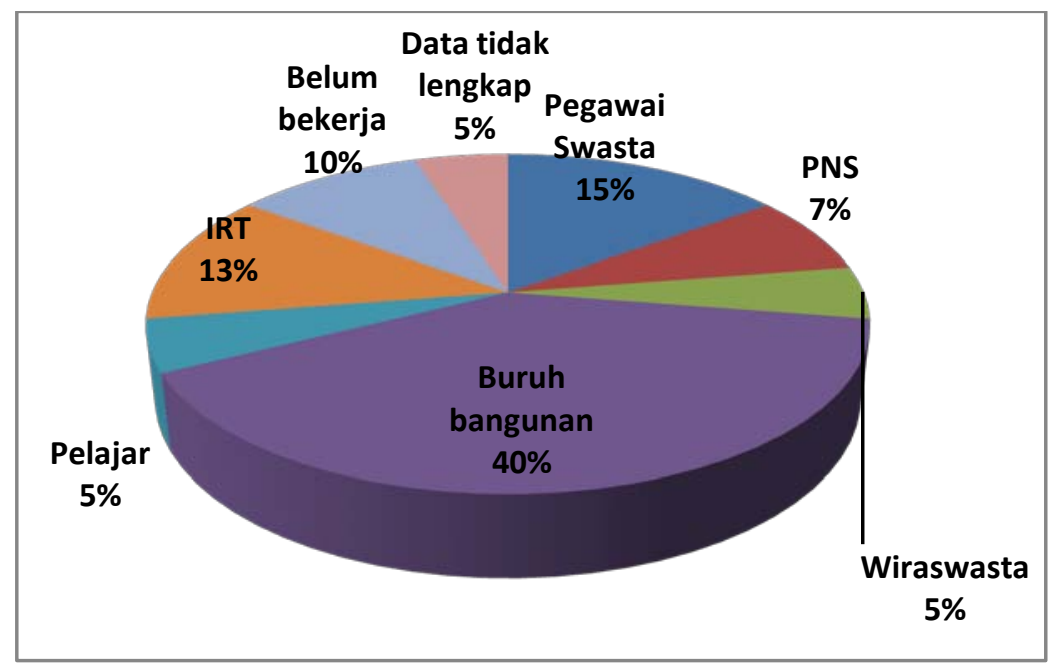

Gambar 3. Distribusi penderita luka bakar listrik berdasarkan pekerjaan

Dari 40 kasus luka bakar listrik yang dirawat di Instalasi Rawat Inap Bedah (Irina A) RSU Prof. Dr. R. D. Kandou Manado periode Agustus 2009 - Agustus 2012, pada tabel III didapatkan insiden tertinggi terjadi pada pekerja buruh bangunan sebanyak 16 kasus (40\%), dan pegawai swasta sebanyak 6 kasus (15\%).

\section{A.1.4. Distribusi menurut besarnya tegangan}

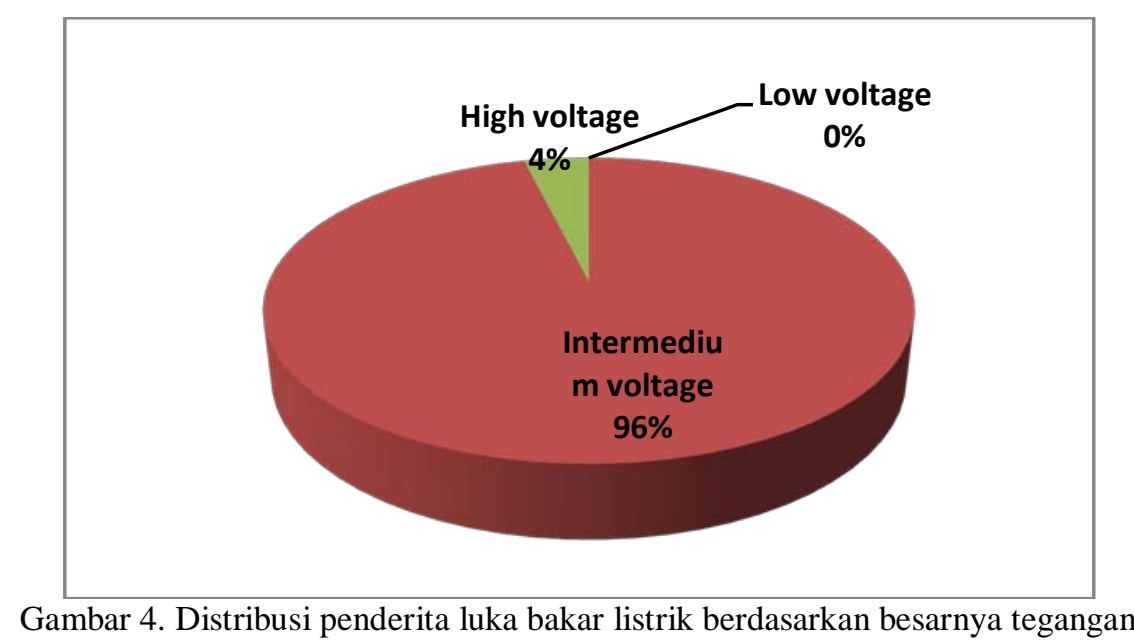

Dari 40 kasus luka bakar listrik yang dirawat di Instalasi Rawat Inap Bedah (Irina A) RSU Prof. Dr. R. D. Kandou Manado periode Agustus 2009 - Agustus 2012, pada tabel IV frekuensi tertinggi berdasarkan distribusi besarnya tegangan terjadi pada arus listrik tegangan menengah (intermedium voltage) yaitu sebanyak 35 kasus (87,5\%) sedangkan sebanyak 5 kasus (12,5\%) terjadi pada arus listrik tegangan tinggi. 


\section{A.1.5. Distribusi menurut keadaan awal pasien}

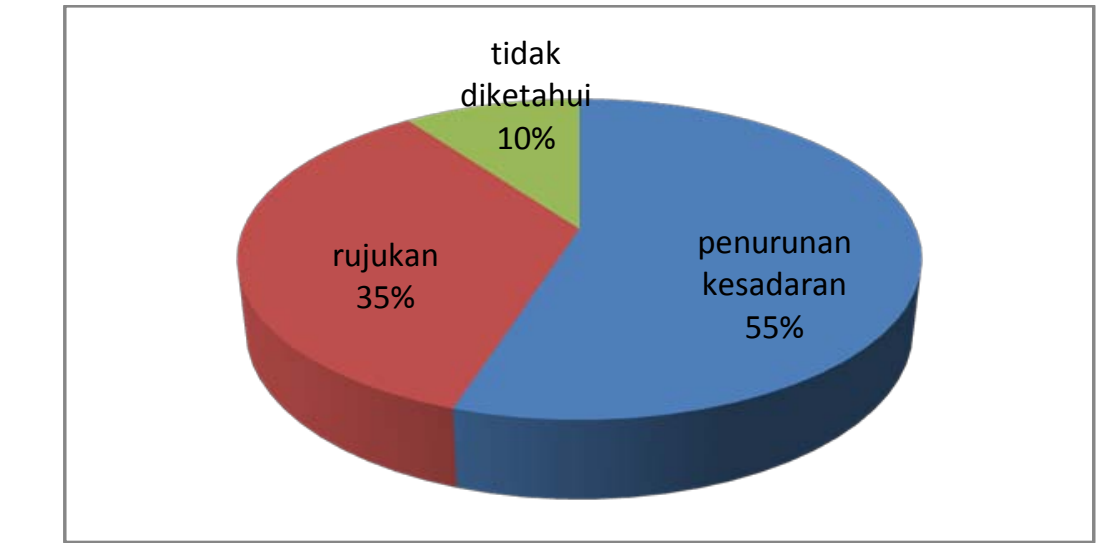

Gambar 5. Distribusi penderita luka bakar listrik berdasarkan keadaan awal pasien

Dari 40 kasus luka bakar listrik yang dirawat di Instalasi Rawat Inap Bedah (Irina A) RSU Prof. Dr. R. D. Kandou Manado periode Agustus 2009 - Agustus 2012, berdasarkan keadaan awal pasien, pada tabel V menunjukkan bahwa sebanyak 22 kasus (55\%) merupakan pasien yang mengalami penurunan kesadaran setelah terkena sengatan arus listrik.

\section{A.1.6. Distribusi menurut keadaan akhir pasien}

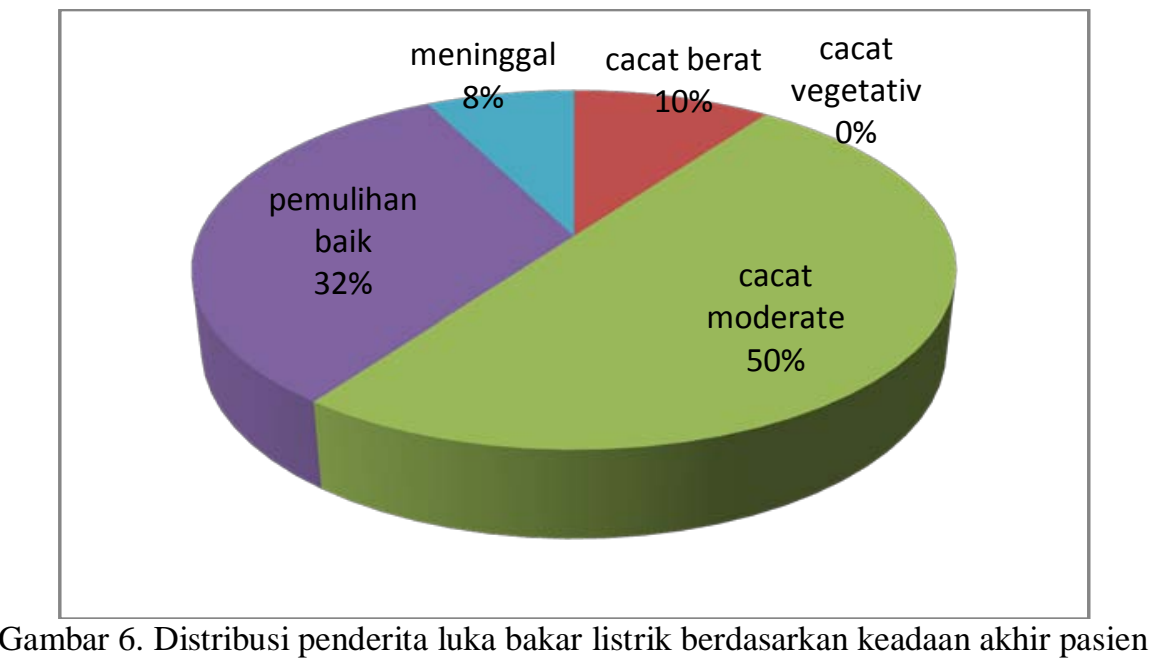

Dari 40 kasus luka bakar listrik yang dirawat di Instalasi Rawat Inap Bedah (Irina A) RSU Prof. Dr. R. D. Kandou Manado periode Agustus 2009 - Agustus 2012, pada tabel Tabel VI menunjukkan bahwa cacat moderat merupakan keadaan akhir yang paling banyak dialami oleh pasien yaitu sebnayak 20 kasus (50\%).

\section{PEMBAHASAN}

Insiden luka bakar akibat listrik berdasarkan hasil pencatatan secara retrospektif deskriptif di Bagian Rekam Medik RSU Prof. R. D. Kandou Manado periode Agustus 2009 - Agustus 2012 didapatkan sebanyak 40 kasus, yang terbagi atas 15 kasus pada periode Agustus 2009 - Agustus 2010, 9 kasus pada periode Agustus 2010 - Agustus 2011, dan pada periode Agustus 2011 - Agustus 2012 didapatkan sebanyak 16 kasus. 
Berdasarkan distribusi menurut umur pada tabel I, luka bakar akibat listrik paling sering ditemukan pada golongan usia 25 - 44 tahun, yaitu sebanyak 24 kasus (60\%). Hasil yang didapatkan ini sesuai dengan teori bahwa insiden luka bakar listrik dan mortalitas mencapai $50 \%$ pada anak $<14$ tahun, $46 \%$ pada umur $15-44$ tahun. $^{2}$

Data pada tabel II menunjukkan bahwa dari 40 kasus luka bakar listrik yang dirawat di Instalasi Rawat Inap Bedah (Irina A) RSU Prof. Dr. R. D. Kandou Manado periode Agustus 2009 - Agustus 2012, berdasarkan jenis kelamin, tabel II menunjukkan bahwa insiden tertinggi terjadi pada pria dengan jumlah kasus sebanyak 30 kasus (75\%) , sedangkan sebanyak 10 kasus (25\%) terjadi pada wanita. Hasil ini sesuai dengan teori yang menyatakan bahwa insiden pada laki-laki berhubungan erat dengan pekerjaan yang beresiko tersengat listrik. ${ }^{11,12}$

Dari 40 kasus luka bakar akibat listrik yang ditemukan di bagian Bedah RSU Prof. R. D. Kandou Manado periode Agustus 2009 - Agustus 2012, pada tabel III ditemukan sebanyak 16 kasus (20\%) terjadi pada sekelompok orang yang berprofesi sebagai buruh bangunan. Berdasarkan teori, jenis pekerjaan ini dikaitkan dengan pekerjaan yang berhubungan dengan penggunaan alat-alat listrik atau mesin di tempat kerja. ${ }^{11}$

Tabel IV menunjukkan bahwa frekuensi tertinggi berdasarkan distribusi besarnya tegangan terjadi pada arus listrik tegangan menengah (intermedium voltage) yaitu 110-220V yang terdapat sebanyak 35 kasus (87,5\%) dan sebanyak 5 kasus $(12,5 \%)$ pada kasus arus listrik tegangan tinggi yaitu $>300 \mathrm{~V}$. Sesuai teori ini disebabkan oleh instalasi rumah tangga yang tidak baik, penggunaan kabel kualitas rendah, tidak adanya pengecekan instalasi listrik secara teratur, penggunaan kabel rol dengan beban berlebihan, serta penggunaan alat-alat listrik yang tidak benar, menyumbang insiden terbanyak cedera akibat listrik pada instalasi rumah tangga. ${ }^{13}$

Bila dilihat keadaan awal pasien luka bakar saat masuk rumah sakit, tabel V menunjukkan bahwa pasien lebih banyak mengalami pingsan setelah terkena sengatan listrik, yaitu sebanyak 22 kasus (55\%). Sesuai dengan teori yang menyatakan bahwa bisa terjadi penurunan kesadaran yang kadang diikuti dengan koma atau kebingungan yang bersifat sementara, yang biasanya akan menghilang dalam beberapa jam atau beberapa hari. ${ }^{2}$

Dari 40 kasus luka bakar listrik yang dirawat di Instalasi Rawat Inap Bedah (Irina A) RSU Prof. Dr. R. D. Kandou Manado periode Agustus 2009 - Agustus 2012, pada tabel Tabel VI menunjukkan bahwa cacat moderat merupakan keadaan akhir yang paling banyak dialami oleh pasien yaitu sebanyak 20 kasus (50\%). Hal ini disebabkan karena pasien memaksakan diri untuk pulang sebelum keadaan pasien benar-benar pulih. Luka bakar listrik terutama yang ringan sampai sedang tidak banyak menyebabkan kerusakan bagian luar karena resistensi kulit lebih tinggi dibandingkan dengan organ-organ lain seperti otot, tendon, saraf. Bila pulih benar, penderita luka bakar listrik hanya mengalami sedikit gangguan pada organ. ${ }^{2}$

\section{SIMPULAN DAN SARAN}

Dari hasil penelitian ini dapat disimpulkan beberapa hal, yaitu: (1) insiden terbanyak adalah terjadi pada umur 25-44 tahun, (2) dengan insiden paling banyak terjadi pada pria, (3) insiden cedera listrik ditempati oleh mereka yang bekerja sebagai buruh bangunan, (4) berdasarkan kuat arus listrik, insiden terbanyak adalah voltase menengah (instalasi rumah tangga), (5) keadaan awal pasien luka bakar listrik terbanyak adalah mereka yang mengalami penurunan kesadaran, dan (6) hasil akhir dari pasien luka bakar listrik menunjukkan bahwa kebanyakan pasien mengalami cacat moderat.

Saran dari penulis untuk dilakukan penelitian yang lebih lengkap dan mendalam tentang profil penderita luka bakar akibat listrik di Bagian Bedah BLU RSU Prof. Dr. R.D. Kandou Manado dikarenakan penelitian ini masih banyak kekurangan, mengingat data rekam medik 
pasien yang tidak lengkap, serta penelitian relative singkat maka untuk mempermudah penelitian selanjutnya, perlu dilakukan perbaikan dan kelengkapannya.

\section{UCAPAN TERIMA KASIH}

Penulis berterima kasih kepada Dr. Alwin Monoarfa, SpB-SpU, Dr. Billy E.Ch.R.Salem,SpB-KBD, dan Dr. Ishak Lahunduitan, SpB-SpBA selaku penguji I, penguji II, dan penguji III. Tidak lupa pula kepada Dr. Alwin Monoarfa, SpB-SpU dan Dr. Mendy Hatibie, SpBP-RE selaku pembimbing I dan pembimbing II, serta kepada semua pihak baik secara langsung maupun tidak langsung telah menumbuhkan ide atau gagasan pada penulis.

\section{DAFTAR PUSTAKA}

1. Gabriel JF. Biolistrik. Fisika kedokteran. Jakarta. EGC. 1996. p 262.

2. Gallagher JJ., Wolf SE., Herndon DN. Burns. Trauma and critical care. Towsend. Sabiston textbook of surgery, $18^{\text {th }}$ ed. Saunders, 2007. Chapter 22.

3. American college of surgeons committee on trauma. Trauma Thermal. ATLS. United State of America. $7^{\text {th }}$ ed. 2004.

4. Cushing AT., et al. Electrical injuries in emergency medicine. [Medscape reference]. 2010. [Updated: April 12, 2010]. Available on : http://emedicine.medscape.com/article/770179-overview\#a0199.

5. Moenadjat Yefta. Luka bakar masalah dan tata laksana. (Edisi ke-4). Jakarta. Balai penerbit FKUI. 2009.

6. Georgiade GS, Pederson WC. Luka bakar: Oswari J, editor. Buku ajar bedah sabiston. Jakarta: EGC; 1995(Pt 1): 151.

7. Kumpulan kuliah ilmu bedah. Luka bakar. Balai penerbit: Binarupa aksara publisher

8. Luka bakar. Nucleus precise news letter \#81. Available on : http://www.google.com/url?sa=t\&rct=j\&q=klasifikasi\%20luka\%20bakar\%20listrik\&sou $\underline{\text { rce }=\text { web\&cd=3\&cad=rja\&ved=0CDUQFjAC\&url=http } \% 3 A \% 2 F \% 2 F w w w . m i r b r o k e r s . c ~}$ om\%2Fdata\%2FNewsletter\%2520Edis\%252081Luka\%2520Bakar1.pdf\&ei=3XL7UPCV DIOrrAfn5IHgCQ\&usg=AFQjCNG_y7LgNrJRl8yioCQk3fz_Hp7GKQ\&bvm=bv.41248 874,d.bmk Uploaded : August 15, 2011

9. Heller JL., et al. Electrical injury. Medline plus. Available on : http://www.nlm.nih.gov/medlineplus/ency/article/000053.htm. Updated : May 1, 2011

10. Koumbourlis AC. Electrical injuries. Critical care medicine. Available on : http://journals.lww.com/ccmjournal/Abstract/2002/11001/Electrical_injuries.7.aspx

11. Daley JD., Geibel John. Electrical injuries. [Medscape reference]. 2012. [Updated: October 3, 2012]. Available on : http://emedicine.medscape.com/article/433682

12. AS Consumer Product safety Commision (CPSC). Available on : http://www.cpsc.gov/cpscpub/pubs/16.html

13. Safety and health in the workplace workplace safety and health health safety in the workplace health and safety at workplace safety and health program. Available on http://www.generateelectricity.net 
